University of Nebraska - Lincoln

DigitalCommons@University of Nebraska - Lincoln

Publications from USDA-ARS / UNL Faculty

U.S. Department of Agriculture: Agricultural

Research Service, Lincoln, Nebraska

2001

Upscaling and Downscaling Methods for Environmental Research

J. L. Hatfield

National Soil Tilth Laboratory, jerry.hatfield@ars.usda.gov

Follow this and additional works at: https://digitalcommons.unl.edu/usdaarsfacpub

Hatfield, J. L., "Upscaling and Downscaling Methods for Environmental Research" (2001). Publications from USDA-ARS / UNL Faculty. 1356.

https://digitalcommons.unl.edu/usdaarsfacpub/1356

This Article is brought to you for free and open access by the U.S. Department of Agriculture: Agricultural Research Service, Lincoln, Nebraska at DigitalCommons@University of Nebraska - Lincoln. It has been accepted for inclusion in Publications from USDA-ARS / UNL Faculty by an authorized administrator of DigitalCommons@University of Nebraska - Lincoln. 


\title{
Upscaling and Downscaling Methods for Environmental Research
}

\author{
J.L. Hatfield * \\ Laboratory Director, USDA-ARS National Soil Tilth Laboratory, 2150 Pammel Drive, Ames, \\ Iowa 50011-4420.
}

Spatial and temporal scales in environmental research cover a wide range. As the research community wants to develop an understanding of the impact of management changes on larger scales, there is often a difficulty because of the lack of tools to effectively transfer data or information among scales. Emphasis on watershed- and regional-scale research requires information being transferred from either observations or models based on smaller scales. How these exchanges of data or model results across both time and space scales can be effectively accomplished is critical to help everyone understand how they can move information across scales. These questions are what the authors have addressed in theory and practice in this book. This book presents the theory that underlays the development of upscaling and downscaling methods and incorporates this theory into a decision support system to aid the user.

The information contained in this book is gleaned from various papers that have been prepared on different scaling studies. The references cited within this book represent applications from a variety of locations and studies and the authors are to be commended for their incorporation of several examples. The outline of the book provides an introduction about the problem of scaling and the general principles of upscaling (aggregation) or downscaling (disaggregation). All of the major terms that the readers need to understand in order to put concepts into practice are defined in a glossary and there are ample figures to visually explain the concepts. The material in the book is presented in an instructive manner that leads the reader through theory into practice. There are only three chapters in the book: an introduction and chapters on upscaling and downscaling. The authors have developed a decision flow diagram that the reader can follow in the book to evaluate the most appropriate method for scaling and asks a series of questions for each step to assist the reader with applying the concepts. This diagram progresses through a series of decisions that a user must address to arrive at the best approach. All of these concepts are incorporated into a decision support system (DSS) that is placed on a CD in the book. A reader can easily install the $\mathrm{CD}$ and practice on the examples. Anytime there is a question, the reader can use the help function, which allows the reader to easily review the theory and 
equations helpful in that portion of the process. The user can apply the DSS to their problem with little trouble. This aspect is an added value to the text that is directed toward helping the reader with their particular application.

Anyone involved in the process of environmental assessment or application of simulation models across a range of scales should read this book. The insights and information contained in this book are extremely helpful and will be of interest and value to students, teachers, and researchers in agriculture, ecology, and environmental sciences. 